\title{
The Representation of Women in the Horror Movies: A Study in Selected Horror Movies
}

\author{
Manaar Kamil Sa'eed, Haider Saad Yahya Jubran \\ English Department, College of Arts, Imam Ja'afar Al, Sadiq University, Baghdad, Iraq \\ Email address: \\ kamilmanaar@yahoo.com (M. K. Sa'eed), haider.jubran1@gmail.com (H. S. Y. Jubran) \\ To cite this article: \\ Manaar Kamil Sa'eed, Haider Saad Yahya Jubran. The Representation of Women in the Horror Movies: A Study in Selected Horror Movies. \\ Communication and Linguistics Studies. Vol. 5, No. 1, 2019, pp. 14-17. doi: 10.11648/j.cls.20190501.13
}

Received: April 8, 2019; Accepted: April 25, 2019; Published: May 20, 2019

\begin{abstract}
Horror can be defined as an intense and painful fear, dread or dismay. It evokes and elicits such kind of emotions in the reader, when rendered in television or cinema. It is a literary genre, which is intended to terrify its readers by calling to mind the feelings of terror and horror. Men are depicted as the slaughterers and victimize women in all kinds of ways. Women in general have a crucial part in most of the horror movies and all the time depicted as the main character in the movie for certain important reasons. The aim of this research is to explore the role of women in the conjuring by Chad Hayes and Carey W. Hayes and The Scream by Kevin Williamson. The study is divided into two sections and a conclusion. Section one deals with a historical background about the horror genre in movies while section two intends to look at the role of women in the horror movies by analyzing the conjuring and the scream. The study ends up with conclusions which sum up the main findings of the research.
\end{abstract}

Keywords: Ghost Story, Women, Horror, Killer, Victims, Conjuring, Scream

\section{Introduction and Background}

\subsection{Section One the Gender Role in Horror Movies}

The horror genre is one of the most fruitful and notorious part of conventional film production. Though it has maintained a notable attractiveness all over its history to the point that there has been no continual period since the 1930 s when terror movies were not being made somewhere in the humankind for this reason horror cinema has become a recognizable part of our culture, even if we do not like watching horror films, but we have an experience of what horror movies actually is and what kind of experience it offers. According to its critics, horror is a recurring and standard area of mass culture. Horror overlaps with other genres like science fiction or the thriller [1].

Horror is the most authoritative feeling in human race and fearing of the mysterious is an ancient concept. One and all has the fear feeling from children to adults. It means playing with the audience feelings. [2] Horror fiction has its genetics in oldest primitive collective perception of humans, legends, rite, exorcisms, shamanist, and religious traditions, focusing on the endless uncertain fears of passing away, eternal life, wickedness, the demonic and the principle of the thing personified in the human being. These were involved over eons in stories of warlocks, witches, devils, ghosts, vampires, and demonic pacts as that of Faust [3].

\subsection{The History of Horror Movies}

A number of the oldest archetypal movies are in the horror genre. For example, an early short film of Frankenstein goes all the way back to 1910. Nosferatu started the vampire film trend all the way back in 1922. Both Frankenstein and Dracula had traditional versions released in 1931. These films seem not very frightening to a contemporary audience, however they are still extensively watched for their historical connotation and sometimes campy acting [4].

Alfred Hitchcock may possibly be the horror movie what Walt Disney was to cartoon. Hitchcock abandoned the campy giants and sprites for a more psychosomatic advance. Hitchcock's movies continue terrifying because of the capture the worldwide terror of the wickedness within men. Psycho, Rear Window, and Vertigo are all incredible examples of movies that leap deep into what scares us, and it often lives below the surface. It also often occupies people we know all too well [5].

Possibly the climax of the horror genre concerning 
reputation appeared with the rise of the slasher movie opening with movies like The Texas Chainsaw Massacre and Halloween, we began to see many characters being disposed gruesomely. The slaughters were inventive, the body counts were high, and the criminal never seemed to pass away though, too much of a superior thing sooner or later watered down the genre. For every Friday the 13th and Sleepaway Camp, there was a Final Exam or Home Sweet Home? [6].

Horror movies turned out to be the superfluous visitor at the festivity for numerous years following the over diffusion of slasher flicks. Then a movie appeared entitled Scream revived the whole genre. How did it supervise that? It took the enjoyment of the 80's horror films and added a critical self-awareness to the actors. The characters felt significant and not narrating wooden conversation. Found recording movies became a chief attaching point with audiences. The Blair Witch Project and Paranormal Activity have amused considerable triumph with nearly no accounts to speak of Saw was also influential in bringing back the dreadful gore of the 80 's movies, but the series were always elegantly written and keeping audiences guessing [7].

\section{Section Two}

\subsection{Women in Horror Movies}

The responsibility of gender is very crucial in the horror genre. It is developed through ages in the old movies, the role of women was naive, powerless and trivial, they just try to scream as a psycho slashed them in a shower, but in 1970s which represents the rise of the feminism in horror movies, female become the central character and they are sufferers who suffered from "sexualized terror." twenty years afterward in Scream, a non-virgin survived, Campbell, who has sexual affair in the film and she is prominent and gorgeous as her school victims. There is no significant improvement in women's position since Scream. [8] In 1920, they involved chaste, guiltless women, who were spiritless and powerless. while in 1990s, women become physically powerful and great. One of the most influential horror movies which incorporates the employment of spirits as a cause of horror is The Conjuring by Chad Hayes and Carey W. Hayes. It is about the story of a simple family which consists of a mother, father and four girls. They moved to a new home in the country, afterward they discovered a boding evil boarded-up underground room and flying pictures, disturbing sleepwalking and terrifying apparitions [9].

\subsection{The Representation of Women in the Conjuring}

Horror movies are well known for them sexist tropes such as the common facts that the "slut" dies first and the "virgin" continues to exist. On the other hand, outside of the slasher genre, these tropes are somewhat inescapable. Actually, The Conjuring, a 2013 terror movie, strays away from all of these humiliating and sexualizing tropes, which is remarkable considering they have a popular feminine cast. In fact, them all female Cast lends itself quite well to analysis [10].

In the movie, there are complementary perception of motherhood and feminine control. On the one hand, there are two optimistic examples of influential mothers in the movie. These two characters are: Carolyn Perron, a mother of five daughters whose family is being obsessed in the movie, and Lorraine Warren, a spiritualist and ghost seeker. These two female figures are fundamental to the events of the movie, and serve as two of the major central characters [11].

On the other hand, the pessimistic example of a dominant mother is the most important antagonist of the movie. This character is the ghost of an accused Bathsheba, witch, who had sacrificed her newborn to the devil and committed suicide long before the events of the movie. Nonetheless, before killing herself, she cursed her land and enabled her spirit to appear and possess anyone who moved there [12].

In general, this distinction of influential females provides a truly attractive collection of characters for the movie. Though there are several male figures, most of them are the other ghost hunters, the female characters certainly provide a more serious part in the definite events and plot of the movie. For instance, although both of Ed and Lorraine are a ghost hunting set, she is the one who is essentially able to sense demonic activity and Ed admits that without her, they would be out of business [13].

However, these influential women can also be a bit conventional. For example, after being haunted by the wicked Bathsheba, it is Carolyn's love for her daughters that eventually allows her to liberate herself of the demonic spirit. She is able, with the help of Lorraine, to spotlight her mind and soul on her love for her daughters and overwhelm the blight. This power is appropriate to her conventional position as a mother rather than some natural power that she possesses, which slightly undermines her depiction as an authoritative female [14].

Interestingly enough, though Lorraine's control is natural to her, it is still portrayed in a fairly conventional way. She is often portrayed as too powerful for her own good and needing of defense. This is first and foremost picked up on during her husband Ed's conversation. In one scene he expresses unease for her health while examine each of the hauntings and says, Whatever Lorraine sees, touches, feels, it helps people, but it also takes a toll on her little piece of her each time." You see and hear Ed showing intense concern for Lorraine and also an instinct to protect her. During one of the final scenes he tries to make her leave before he performs an exorcism to protect her, but she refuses and says they are a team [15].

Thus, the conjuring is considered feminine movie for the reason that it reveals women as the Exorcist, which is based on the knowledge of real life mystical examiners and a married couple. Its resolution centers on the view that women share a universal connection that can eventually help them discuss and cope with disturbing events including demonic possession [16].

\subsection{The Representation of Women in the Scream Movie}

Horror movies have a fascinating system of portraying women. They have a tendency to be the genre where a woman 
can have the role of the "hero" in the narrative, however, the overestimated sex symbol and victim. The expression "Scream Queen" derived from the representation of women as sufferers, who shout for aid. Jamie Lee Curtis' personality in the Halloween film is the major instance of a woman repeatedly offended and screaming for help whilst a "madman" is attempting to slaughter her [17]. Slasher movies, a subgenre of horror cinema, have become synonymous with victimizing women using to not survive and should be undo, quieten, violence closed Lgraphic. [18] While there are other movies that have broken the style and tried to illustrate a woman as a physically powerful character, she is still eventually, a victim. An instance of this sort of personality is Neve Campbell's character, Sydney Prescott, from "the Scream franchise". Sydney is distinguished as smart, and sneakiness girl with a disturbed past, yet she is ever enduring. When people in her life turn out to be victims of a cruel sequential murderer, she becomes the ideal goal: attractive young, and innocent. Sydney shows to be stronger and powerful than the murderer imagined and in their final fight, Sydney overwhelms the tag team of murderers by electrocuting one with a TV and gunfire the other, numerous times [19]. This thought of a feminine figure making it to the end of the movie is called "The Final Girl" character. The Final Girl is the last character to stay alive out of her member sufferers (frequently her best friends or one of her family) and will slaughter her enemy. This female makes it to the end by being a virginal and pure figure of a conventional "good" girl. This communicates the audience that you will be savagely murdered by the killer, if you have sex [20].

Cowan and O'Brien (2009) mentioned that "Quantitative content analysis research has shown that "female non-survivors were frequently engaged in sexual behavior immediately preceding the slashing." This reality is made very obvious in horror movies. Scream sarcastically made fun of it in the final argument. One of the murderers, Stu, says "That's right and now you're no longer a virgin. You gotta die - those are the rules". Since Sydney made sex with Billy, her boyfriend (who is the other murderer), she has to pass away to pursue the "rules". These regulations do not seize male figures to the same customary. It is only the female that is appeared on screen making sex and then murdered [21].

It is also motivating to note that not often is a women portrayed as the murderer in a horror movie. There have been women as co-killers (Scream 2) or have some type of outside influence such as being alien, werewolf a vampire, ghost, or curse (Let the Right One in, The Ring, Species, Ginger Snaps, Jennifer's Body). Rarely is a women depicted as a cold-blooded sequential murderer without an external power. Horror films are all about cheap thrills and shock-value possibly women will get identical depiction as both the murderer and the victim whereas not much can be learned about society through horror movies, as a trendy amusement genre, it should signify both genders. According. to Smith (2010), "Exposure to such distorted "reel" world images may be having detrimental effects on youth's gender-roles of civilization" [22].

Bugler states (1992), “At the level of group analysis, children generally remember gender-stereotypic information better than counter stereotypic information although occasionally the reverse is observed" and "at the level of individual differences, children with relatively more stereotyped attitudes usually show significantly better memory for stereotypic than counter stereotypic information" [23].

Smith agrees with Bigler, "Children who watch skewed portrayals of males and females while they are developing cognitively may organize their view on gender into schemas driven by these stereotypes". [24] The influences of gender stereotypes on matures is less cruel than on children because adults have developed their thoughts on gender. "Zillma et al. (1986) determined that male and female enjoyment of horror films is a function of moviegoers' level of attraction to companions of the opposite gender". [25] As both men and women enjoy watching movies for amusement, they are naive of the fundamental concepts of gender stereotypes that are being refreshed in their minds. According to Bleakley (2012), "Repeated exposure to gender imbalance, sexual depictions of women, and violent depictions of men may affect gender-related attitudes and beliefs of young men and women as well as their normative beliefs about the extent to which their peers are engaging in sexual activity and violent behavior" [26].

\section{Conclusions}

Horror movies depict female characters as sexual, helpless victims. When horror movies try to reveal female characters as the hero of the story, this gave a message to audiences that women can be powerful and independent. An experiment was conducted to test an audience's perceptions gender stereotypes of women in the horror film, Scream. Results indicate that stereotypes. present in the horror film effected. The participants' perception of women as competent heroes. Female participants were also more likely to perceive women as more competent than male participants.

Horror movies especially ghost story movies, are created for more than one reason: firstly, for the sake of entertainment, secondly, to frighten the audience, and finally, to invoke the audiences fear in a horrible and shaken way. Psychologically, horror movies are invoked by the use of killers, monster, aliens especially in modern horror movies.

Overall, despite the somewhat sexist framework that demands the women be protected and saved, the film unashamedly presents female characters with power. The women do not back down in the face of danger, but are committed to protecting the people around them. They are bold and sacrificing, which is also what enables them to stand up for themselves when the men attempt to undermine them. This strength and determination stand out more in the film than the stereotypes, making these women some of the more important characters in the horror genre. 


\section{End Note}

\section{Section One}

1) Peter Hutchings, Historical Dictionary of Horror Cinema, 43.

2) Robert Sheppard's Literary Blog \& World Literature Forum,

Posted on March 3, 2018)

3) Ibid.

4) http://www.deliberatemagazine.com/brief-history-horror-films/

5) Ibid.

6) Ibid.

7) Ibid.

\section{Section Two}

8) Kiri Blakerley, Women in Horror Films, 2010.

9) Ibid.

10) Kelsey Knoploh, Mar 2, 2018.

11) Ibid.

12) The Conjuring. Dir. James Wan. Perf. Vera Farmiga and Patrick Wilson. New Line Cinema, 2013. Film.

13) Ibid.

14) Ibid.

15) Kelsey Knoploh, Mar 2, 2018.

16) Christopher J. Olson، CarrieLynn D. Reinhard Possessed Women, Haunted States: Cultural Tensions in Exorcism Cinema, 2016, p. 162.

17) Keisner, 2008; Walsh, 2010.

18) Linz \& Donnerstein, 1994; Walsh, 2010.

19) Weinstein \& Craven, 1997.

20) Lizardi, 2010; Welch, 2010.

21) Weinstein \& Craven, 1997.

22) Smith 2010, p. 774.

23) Bigler 1992, p. 352.

24) Smith, 2010, p. 783.

25) Nolan, 2000, p. 40.

26) Bleakley 2012, p. 73.

\section{References}

[1] Bigler, R. S., \& Liben, L. S. (1992). Cognitive Mechanisms in Children's Gender Stereotyping: Theoretical and Educational Implications of a Cognitive-Based Intervention. Child Development, 63(6), 1351-1363.

[2] Blakerley, Kiri. Women. in Horror Films, 2010.
[3] Bleakley, A., Jamieson, P., \& Romer, D. (2012). Trends of Sexual and Violent Content by Gender in Top-Grossing U.S. Films, 1950-2006. The Journal of Adolescent Health, 51(1), 73-79.

[4] Dir. James Wan. Perf. Vera Farmiga and. Patrick Wilson., The Conjuring. New Line. Cinema, 2013. Film.

[5] Hutchings, Peter. Historical Dictionary of Horror Cinema, 2017. P 43. Retrieved from https://books.google.iq/books?isbn=1538102447

[6] Keisner, J. (2008). Do You Want to Watch? A Study of the Visual Rhetoric of the Postmodern Horror Film. Women's Studies 37(4) 411-427.

[7] Kelsey Knoploh, Women in the conjuring. Mar 2, 2018. https://medium.com/comm430gu/women-in-the-conjuring-d7c $338994 \mathrm{e} 9 \mathrm{~b}$

[8] Nolan, J., \& Ryan, G. (2000). Fear and loathing at the cineplex: Gender differences in descriptions and perceptions of slasher films. Sex Roles, 42.1(2), 39-56.

[9] Linz, D., \& Donnerstein, E. (1994). Sex and violence in slasher films: A re-interpretation. Journal of Broadcasting and Electronic Media, 38, 243-247.

[10] Lizarde, R. (2010) "Re-Imagining" Hegemony and Misogyny in the Contemporary Slasher Remake. Journal of Popular Film and Television 38(3) 113-121.

[11] Olson, Christopher J. and D. Reinhard, CarrieLynn. Possessed Women, Haunted States: Cultural Tensions in Exorcism Cinema, 2016, p. 162.

[12] Sheppard, Robert. Literary Blog \& World Literature Forum, Posted on March 3, 2014.

[13] Smith, S., Pieper, K., Granados, A., \& Choueiti, M. (2010). Assessing Gender-Related Portrayals in Top-Grossing G-Rated Films. Sex Roles, 62(11-12), 774-786.

[14] Weinstein, B. (Producer), \& Craven, W. (Director). (1997). Scream [Motion picture]. USA: Dimension Home Video.

[15] Welsh, A. (2010). On the perils of living dangerously in the slasher horror film: gender differences in the association between sexual activity and survival. Sex Roles, 25(1/2), 197-213.

[16] http://www.deliberatemagazine.com/brief-history-horror-films/ 